\title{
PEMERIKSAAN RADIOLOGI GIANT BULLOUS LUNG DISEASE
}

\author{
Fauzy Ma'ruf \\ Fakultas Kedokteran Universitas Islam Al-Azhar \\ Jl. Unizar No.20 Turida Mataram \\ Email : fauzyma69ruf@gmail.com
}

\begin{abstract}
ABSTRAK
Giant bullous lung disease adalah suatu kondisi klinis yang ditandai oleh bullae berukuran besar yang volumenya cukup signifikan. Kriteria radiologi untuk kelainan tersebut adalah adanya giant bullae di satu atau kedua apeks paru, meliputi minimal sepertiga hemitoraks dan mengkompresi parenkim paru normal di sekitarnya. Pada dewasa, faktor resikonya dapat berupa kebiasaan merokok, defisiensi alfa-1 antitripsin, sedangkan pada anak dapat disebabkan kondisi idiopatik, dan late sequelae penyakit paru kronik yang terkait dengan kelahiran prematur. Giant bullae dapat terjadi akibat komplikasi dari emfisema. Pasien dengan bullae mungkin asimtomatik, namun dengan semakin membesarnya ukuran bullae, dapat menimbulkan keluhan dispneu, nyeri dada, maupun hemoptisis. Pemeriksaan radiologi untuk menegakkan diagnosis yaitu; foto toraks, ct scan toraks, ultrasonografi toraks, kedokteran nuklir dan angiografi
\end{abstract}

Kata Kunci: Giant bullous lung disease, foto toraks, ct scan toraks, ultrasonografi toraks, kedokteran nuklir, angiografi

\section{PENDAHULUAN}

Giant bullous lung disease adalah suatu kondisi klinis yang ditandai oleh bullae berukuran besar yang volumenya cukup signifikan. Kriteria radiologi untuk kelainan tersebut adalah giant bullae di satu atau kedua apeks paru, meliputi minimal sepertiga hemitoraks dan mengkompresi parenkim paru normal di sekitarnya

Bullous lung disease berbeda dengan bullous emphysema. Burke (1937) pertama kali mendeskripsikan bullous lung disease sebagai suatu sindroma klinis yang karakteristik ditandai oleh adanya bullae di satu

Jurnal Kedokteran

Vol. 06 No. 01 Desember 2020 atau kedua apeks paru dengan struktur parenkim paru yang normal. Sementara bullous emphysema adalah bullae yang terjadi pada pasien Penyakit Paru Obstruksi Kronis ( PPOK), dimana telah terjadi abnormalitas parenkim paru yang difus. Namun dalam beberapa literatur, kedua istilah tersebut seringkali dianggap serupa, sehingga istilah giant bullous lung disease kadang disebut juga sebagai giant bullous emphysema.

Secara historis, istilah bullae, kista, dan bleb seringkali digunakan bergantian. Namun pada dasarnya, ketiga istilah tersebut harus 
dibedakan. Kista pada paru adalah suatu kista bronkial atau bronkogenik yang tepinya dibatasi oleh epitel respiratorium. Bleb adalah rongga berisi udara di subpleural, yang terjadi dari rupturnya alveolus. Bullae adalah rongga berisi udara di dalam parenkim paru, dimana sebagian besar tepi bagian luar bullae dibatasi oleh pleura viseralis, sementara tepi bagian dalam dibentuk oleh jaringan fibrous yang berasal dari parenkim paru di sekitarnya yang mengalami kerusakan (Fatimi SH, 2012)

\section{ETIOLOGI}

Penyebab bullous lung disease berbeda antara anak-anak dan dewasa. Pada dewasa, penyebab atau faktor resikonya dapat berupa kebiasaan merokok (penyebab terbanyak), defisiensi alfa-1 antitripsin, serta penyalahgunaan obat terlarang, sedangkan pada anak- anak dapat disebabkan oleh beberapa kondisi, yaitu idiopatik, late sequelae penyakit paru kronik yang terkait dengan kelahiran prematur:

Bronchopulmonary Dysplasia (BPD), serta Pulmonary Interstitial Emphysema (PIE). Perubahan emfisematosa pada BPD dapat Jurnal Kedokteran Vol. 06 No. 01 Desember 2020 asimetris, gambarannya kadang berupa bullae berukuran besar yang menyerupai pneumotoraks (Gambar $1)$.

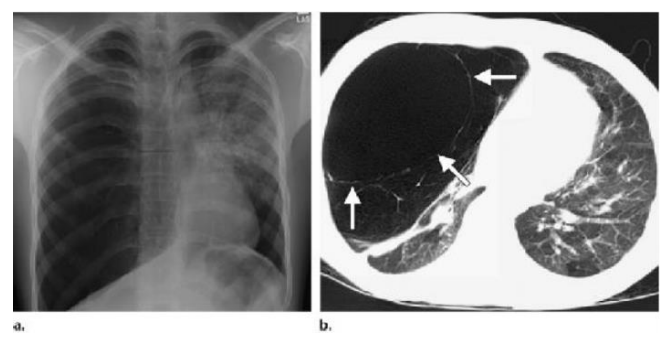

Gambar 1. (a) Foto toraks menunjukkan hiperekspasi paru kanan dengan lusensi yang nyata, yang mendeviasi mediastinum ke kiri. Opasitas di lobus superior paru kiri adalah akibat proses kronis dari kelahiran prematur dan atelektasis. (b) CT Scan potongan aksial menunjukkan area hiperlusen dan hiperekspansi di paru kanan, sebagai akibat dari emfisema berat. Tampak pula bullae besar (panah) berdinding tipis (Dilman Jr, 2011)

\section{EPIDEMIOLOGI}

Giant bullous lung disease adalah kelainan yang sebagian besar menyerang pria perokok usia muda, walaupun dapat terjadi pada bukan perokok dengan defisiensi alfa- 1 antitripsin. Pada anak-anak, giant bullous lung disease jarang terjadi. Tidak ada literatur yang menyebutkan 
secara pasti jumlah atau persentasi kejadiannya.

\section{PATOFISIOLOGI}

Giant bullae dapat dikatakan sebagai komplikasi dari emfisema Karkhanis VS， 2010). Emfisema menyebabkan hilangnya elastisitas dinding alveoli. Pada perjalanannya, dinding alveoli akan meregang menjadi lebih besar namun kurang efisien dalam proses pertukaran oksigen dan karbon dioksida selama proses pernafasan berlangsung. Kesulitan dalam proses ekspirasi akan mengarah pada terperangkapnya udara di dalam pulmo, yang dikenal sebagai hiperinflasi.

\section{MANIFESTASI KLINIS}

Pasien dengan bullae mungkin asimtomatik, pada kondisi ini diagnosis ditegakkan dari pemeriksaan foto polos toraks rutin. Dengan semakin membesarnya ukuran bullae, akan menimbulkan keluhan berupa sesak, nyeri dada, serta kadang terjadi hemoptisis. Kadang dapat terjadi sesak nafas berat akibat terjadinya pneumotoraks spontan atau peningkatan ukuran bullae secara mendadak akibat udara yang terperangkap. Meningkatnya frekuensi batuk disertai sputum umumnya mengindikasikan terjadi infeksi pada bullae.

\section{DIAGNOSIS}

Diagnosis ditegakkan untuk menentukan apakah fungsi paru terhambat akibat tekanan dari giant bullae atau adakah efek secara umum yang berasal dari emfisema yang mendasari. Pemeriksaan radiologi untuk menegakkan diagnosis meliputi: foto polos toraks, CT Scan toraks, USG, Nuklir dan Angiografi.

\section{PEMERIKSAAN RADIOLOGI}

\section{Foto polos toraks}

Foto polos toraks adalah metode yang paling praktis untuk mengidentifikasi adanya bullae dan progresifitasnya. Namun kadang sulit membedakan bayangan dinding bullae dari kavitas atau kista di parenkim paru ( Gambar 2). Foto polos yang dibuat saat ekspirasi maksimal dapat membantu menunjukkan adanya bullae, dimana udara yang terperangkap selama proses ekspirasi akan mempertegas dinding bullae. Bullae berukuran besar dapat mendeviasi mediastinum 
ke arah kontralateral dan bahkan mengkompresi paru kontralateral.

Kriteria radiografi untuk mendiagnosis giant bullous lung disease yaitu adanya giant bullae di salah satu atau kedua lobus superior paru dan mengisi minimal sepertiga hemi toraks serta mengkompresi parenkim paru normal di sekitarnya. Stern et al menggambarkan temuan radiografi pada foto polos thorax dan CT Scan thorax dari giant bullous lung disease, yaitu berupa multipel bullae berukuran besar dengan diameter 1-20 cm, umumnya antara 2$8 \mathrm{~cm}$, tanpa adanya bullae tunggal yang dominan (Sharma N, 2009).

Komplikasi utama dari giant bullous lung disease adalah pneumotoraks, yang dapat menyebabkan kerusakan akut pada fungsi pernapasan yang berhubungan dengan nyeri dada. Infeksi pada bullae juga sering terjadi.

\section{CT Scan Toraks}

Computed Topografi (CT) scan torak adalah metode pencitraan yang paling akurat untuk mendiagnosis giant bullae, terkait dengan penatalaksaan secara operatif. Bullae diidentifikasi sebagai area yang tidak

Jurnal Kedokteran

Vol. 06 No. 01 Desember 2020 mengandung pembuluh darah dan dibatasi oleh dinding yang tegas. Ukuran, lokasi, serta jumlah bullae dapat tervisualisasi dengan jelas. Visualisasi dinding luar bullae penting untuk membedakannya dengan pneumothorax.

\section{Ultrasonografi Toraks}

Beberapa penelitian telah mendapatkan hasil bahwa USG dapat mendeteksi bullae serta membedakan dengan pneumotoraks. Pada bullous disease akan terlihat fenomena 'comet tail', yaitu pergeseran jaringan paru terhadap pleura selama proses respirasi. Pada pneumotoraks, jaringan paru yang terlibat akan mengalami kolaps, sehingga fenomena tersebut tidak akan tampak.

\section{Kedokteran Nuklir}

Evaluasi pra-operasi dapat dilakukan dengan teknik kedokteran nuklir. Scan perfusi memberikan penilaian kualitatif terhadap vaskularisasi paru. Namun peran scan ventilasi perfusi dalam melokalikasi bullae saat ini telah digantikan oleh CT Scan, karena CT Scan terbukti merupakan metode pemeriksaan noninvasive terbaik dalam 
mengevaluasi arsitektur jaringan paru serta mengevaluasi bilamana terdapat penyakit yang mendasari timbulnya bullae.

\section{Angiografi}

Angiografi dapat memberikan informasi yang berguna mengenai area pulmo yang tidak terpengaruh oleh bullae, namun informasi tersebut tidak selalu diperlukan. Jika pembuluh darah di sekitar bullae tampak intak dan ramai, memberikan kemungkinan cukup tinggi untuk membaiknya fungsional jaringan pulmo setelah tindakan bulektomi ( gambar 2). Bila pembuluh darah di sekitar bullae tampak tak intak dan minimal, akan memberikan ada kemungkinan hasil yang kurang baik setelah reseksi bullae.

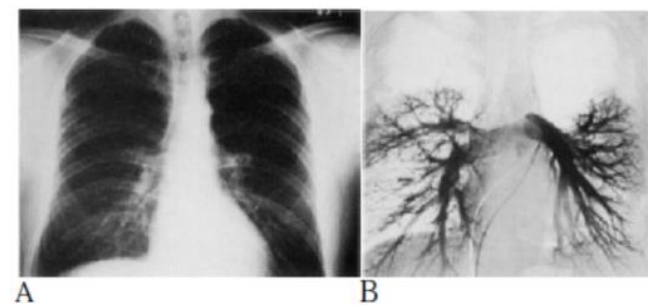

Gambar 2. (A) Foto thorax menunjukkan bulla besar di kedua apeks pulmo. (B) Angiogram pulmo menunjukkan vaskularisasi yang intak namun prominent.

\section{DAFTAR PUSTAKA}

Dilman JR, Sanchez R, Torres MFL, Yarram SG, Strouse PJ, Lucaya J. Expanding upon the Unilateral Hyperlucdent Hemithorax in Children. RadioGraphics. 2011; 31: 723-41.

Fatimi SH, Jafferani A, Ashfaq A. Giant Pulmonary Bulla with Mediastinal Shift in a $12 \frac{1}{2}$ year old Girl. J Pak Med Assoc. 2012; 62 (5): 503-4.

Karkhanis VS, Joshi JM. Autobulectomy in Idiopathic Giant Bullous Lung Disease. Indian J Chest Dis Alled Sci. 2010; 52: 159-60.

McLoud TC, Boiselle PM. Congenital Abnormalities of the Thorax. In: McLoud TC, Boiselle PM. Thoracic Radiology, The Requisites. 2nd ed. USA. Mosby Elsevier; 2010. pp 59-79.

Shah NN, Bhargava R, Ahmed Z, Pandey DK, Shameem M, Bachh AA, et al. The Vanishing LungAnswer, Diagnostic Challenge. Canadian Journal of Emergency Medicine. 2007; 9 (3): 2333-4.

Sokouti M, Golzari S. A Giant Bulla of Lung Mimicking Tension Pneumothorax. J Cardiovasc Thirac Res. 2010; 2 (2): 41-4.

Sharma N, Justaniah AM, Kanne JP, Gurney JW, Mohammed TH. Vanishing Lung Syndrome (Giant Bulloue Emphysema): CT Findings in 7 Patients and a Literature Review. J Thorac Imaging. 2009; 24: 227-30.

Weathers E. The Anatomy of the Pediatric Airway. Brockton. RCEducational Consulting Services, Inc; 2010. pp 1-21. 